\title{
Konsep Pengembangan Aerotropolis di Bandara Internasional Sultan Hasanuddin Makassar
}

\section{Aerotropolis Development Concept At Sultan Hasanuddin International Airport Makassar}

\author{
Randy Obertias O. Sumarata ${ }^{1}$, Murshal Manaf ${ }^{2}$, Syafri $^{2}$ \\ ${ }_{1}^{1}$ Magister Perencanaan Wilayah dan Kota Program Pascasarjana Universitas Bosowa \\ ${ }^{2}$ Program Studi Perencanaan Wilayah dan Kota, Program Pascasarjana, Universitas Bosowa \\ E-mail: randy.obertias@gmail.com
}

Diterima: 20 Februari 2021/Disetujui 07 Juni 2021

\begin{abstract}
Abstrak. Penelitian ini bertujuan untuk Menganalisis karakteristik pelayanan Bandara Internasional Sultan Hasanuddin Makassar dalam mendukung konsep aerotropolis dan Mengkaji konsep pengembangan aerotropolis di Bandara Internasional Sultan Hasanuddin Makassar. Penelitian ini merupakan jenis penelitian deskriptif kuantitatif dengan menggunakan alat analisis diantaranya analisis deskriptif kuantitatif skala likert (crosstabulation) dan analisis jalur/analisis path. Sampel yang digunakan sebanyak 100 orang. Data diperoleh dari Badan Pusat Statistik dan lainnya serta masyarakat yang menjadi responden dengan menggunakan kuesioner/wawancara. Hasil penelitian menunjukan bahwa karakteristik pelayanan Bandara Internasional Sultan Hasanuddin Makassar dalam mendukung konsep aerotropolis berdasarkan karakteristik aerotropolis yakni Prinsip Struktur Ruang, Prinsip Jarak/Aksesibilitas, Prinsip Zonasi, Prinsip Tata Guna Lahan, Prinsip Peruntukkan Utama Fungsi Kawasan, Prinsip Penyediaan Kawasan Bisnis, Prinsip Integrasi dan Prinsip Konektivitas memiliki pengaruh didalam pengembangannya. Untuk mengkaji konsep pengembangan aerotropolis di Bandara Internasional Sultan Hasanuddin Makassar berdasarkan karakteristik aerotropolis memiliki pengaruh baik secara langsung maupun tidak langsung. Hasil analisis ini menunjukan bahwa karakteristik yang memiliki pengaruh signifikan secara tidak langsung didalam pengembangannya yakni prinsip integrasi dan konektivitas. Hal ini ditandai dengan pengembangan bandara ke aerocity agar dapat menuju kekonsep aerotropolis dimana menyediakan infrastruktur dasar agar segala aktivitas didalamnya dapat terhubung dengan baik.
\end{abstract}

Kata Kunci : Konsep Aerotropolis, Karakteristik Pelayanan, Bandara

\begin{abstract}
This study aims to analyze the service characteristics of Sultan Hasanuddin International Airport Makassar in supporting the aerotropolis concept and examine the concept of aerotropolis development at Sultan Hasanuddin International Airport Makassar.This research is a type of quantitative descriptive research using analytical tools including quantitative descriptive analysis of the Likert scale (crosstabulation) and path analysis. The sample used was 100 people. Data obtained from the Central Bureau of Statistics and others as well as the community who became respondents using a questionnaire / interview. The results show that the service characteristics of Sultan Hasanuddin International Airport Makassar are in support of the aerotropolis concept based on aerotropolis characteristics, namely the Principle of Spatial Structure, the Principle of Distance / Accessibility, the Principle of Zoning, the Principle of Land Use, the Principle of Main Allocation of Regional Functions, the Principle of Provision of Business Areas, the Principle of Integration and The principle of connectivity has an influence on its development. To study the concept of aerotropolis development at Sultan Hasanuddin International Airport, Makassar, based on the characteristics of the aerotropolis, has a direct or indirect effect. The results of this analysis indicate that the characteristics that have an indirect significant influence in its development are the principles of integration and connectivity. This is marked by the development of airports to aerocity in order to get to the concept of aerotropolis which provides basic infrastructure so that all activities in it can be well connected.
\end{abstract}

Keywords: Aerotropolis Concept, Service Characteristics, Airport

\section{Pendahuluan}

Konsep pengembangan bandara didunia pada awalnya hanya sebagai kebutuhan komersial penerbangan saja tanpa memperhatikan dampak yang lebih luas dari bandara tersebut. Melihat fenomena ini, (John Kasarda, 2000) memperkenalkan sebuah konsep pengembangan kota berbasis bandara atau disebut dengan aerotropolis. Aerotropolis pada dasarnya memandang bahwa bandara bukan hanya sebagai sarana naik dan turunnya pesawat melainkan dapat memberi pengaruh pada daerah sekitar bandara dan menjadi stimulan generator pada pertumbuhan ekonomi masyarakat. Negara-negara seperti Belanda, Korea Selatan dan Amerika yang menerapkan konsep aerotropolis telah membuktikan konsep aerotropolis dapat meningkatkan kontribusi ekonomis yang sangat signifikan bagi daerah dan negara yang bersangkutan. Aerotropolis merupakan tata kota urban yang desain, infrastruktur, dan ekonominya berpusat pada sebuah bandar udara, (John 
Kasarda, 2000). Tujuan aerotropolis adalah meningkatkan efektivitas, efisiensi, dan pembangunan ekonomi berkelanjutan yang meletakkan bandara sebagai pusat pertumbuhan dan konektivitas dengan pasar global.

Perkembangan penduduk perkotaan senantiasa mengalami peningkatan maka tuntutan akan kebutuhan kehidupan dalam aspek ekonomi, sosial, dan budaya juga terus mengalami peningkatan (Northam dalam Yunus, 1994) . Oleh karena ketersediaan ruang di dalam kota sifatnya tetap dan terbatas, maka meningkatnya kebutuhan ruang untuk tempat tinggal dan kedudukan fungsi-fungsi akan mengambil ruang di daerah pinggiran kota. Lahir dan tumbuhnya kota selalu terdefinisi sejalan dengan sarana transportasi dan teknologi yang ada saat itu (Surya et al, 2020).

Perkembangan kota pada saat ini menunjukkan kemajuan yang pesat sejalan dengan bertambahnya jumlah penduduk serta semakin besarnya volume kegiatan pembangunan pada berbagai sektor. Hal ini menyebabkan semakin bertambah dan berkembangnya sarana dan prasarana pendukung yang selalu menuntut adanya perubahan-perubahan yang mengarah pada kualitas dan kuantitasnya. Pertumbuhan penduduk dan peningkatan aktivitas kota di Indonesia menyebabkan banyak berkembangnya kawasan komersial. Salah satu sektor yang perlu diperhatikan untuk mengantisipasi perkembangan kawasan komersial ini adalah penanganan masalah transportasi. Hal ini karena transportasi merupakan salah satu aspek yang sangat penting dan memegang peranan yang sangat strategis dalam perkembangan dan pertumbuhan suatu wilayah maupun pemerataan hasil-hasil pembangunan yang ada. Keberadaan pusat kawasan kegiatan ini menyebabkan adanya tarikan pergerakan akibat adanya aktivitas di kawasan tersebut. Tarikan pergerakan ini merupakan pergerakan orang yang melakukan perjalanan dari tempat asal menuju ke kawasan komersial tersebut.

Pembangunan transportasi dan pengembangan wilayah memiliki hubungan yang sangat erat dan saling berkesinambungan. Pembangunan transportasi harus berbasis pada pengembangan wilayah dan transportasi merupakan kekuatan pembentuk pertumbuhan dan pembangunan ekonomi wilayah (Adisasmita, 2011). Terlepas dari proses, bandara terus berubah dari infrastruktur transportasi udara utama menjadi multimodal, perusahaan multi fungsional yang menghasilkan pembangunan komersial cukup besar berada di dalam dan juga di luar dari batas bandara. Saat ini, secara tidak disadari semua dari fungsi komersial pusat suatu metropolitan dapat ditemukan pada atau dekat dengan bandara. Hal tersebut membuat bandara yang tadinya bandara kota menjadi kota bandara (J. Kasarda, 2013).

Belakangan ini terdapat model strategi pendekatan untuk pengembangan area bandara untuk meningkatkan daya saing bisnis dan kota sekitarnya dengan cara meningkatkan kepentingan bandara tersebut di seluruh dunia, model strategi tersebut adalah Aerotropolis (J. D. Kasarda \& Appold, 2014). Aerotropolis merupakan sub wilayah perkotaan yang infrastruktur, tata guna lahan, dan ekonominya semua berpusat di bandara. Nilai utama Aerotropolis berada pada penawaran bisnis yang memiliki jaringan yang cepat antara produsen, konsumen, dan mitra usaha secara nasional dan internasional yang meningkatkan keuntungan perusahaan dan daerah. Secara spasial, jika perkotaan biasanya terbentuk dari pusat kota dan commuter-linked suburbs, Aerotropolis terdiri dari airport city sebagai nukleus dan di sekitarnya terdapat klasterklaster bisnis terhubung aviasi yang terasosiasi dengan pembangunan residensial. Klaster tersebut dapat ditemui dalam radius sampai 20 mil (32 kilometer) dari hub bandara tersibuk dengan dampak ekonomi yang signifikan dan dapat diukur hingga 60 mil (96 kilometer) (Bonnat, 2013, dalam Kasarda \& Appold, 2014).

Permintaan terhadap transportasi udara di Indonesia saat ini lebih tinggi jika dibandingkan dengan PDB perkapita Indonesia. Saat ini ASEAN memiliki kebijakan single aviation market. Kebijakan itu membuat bandara di Indonesia harus mengembangkan infrastruktur bandaranya untuk memenuhi kebutuhan atas permintaan transportasi udara. Single aviation market dapat meningkatkan frekuensi aktivitas bisnis yang berpusat di bandara yang akan meningkatkan daya saing kawasan bisnis kota di sekitar bandara yang memiliki akses cepat dan terintegrasi dengan bandara.

Arah perkembangan kota makassar yang mengarah keluar tentunya menjadi perhatian dimana pengembangan konsep aerotropolis akan menimbulkan munculnya permasalahan baru seperti masalah lahan pertanian menjadi non pertanian dan lain sebagainya. Fenomena modernisasi dan suburbanisasi pada kawasan pinggiran terjadi akibat tuntutan pembangunan fisik yang cukup tinggi, sehingga memengaruhi arah perkembangan fisik sebuah kota.

Pertumbuhan Kota Makassar berlangsung cukup pesat dan memberikan pengaruh kepada kota-kota di sekitarnya, baik dalam perkembangan kota inti maupun efek limpahan kegiatan ke kota-kota sekitarnya. saat ini kota makassar dalam kedudukannya sebagai kota inti dalam wilayah Metropolitan Mamminasata, ditandai dengan proses urbanisasi dan migrasi desa-kota yang berlangsung sangat intensif salah satu contohnya daerah peri urban kota Makassar, yakni kabupaten Takalar (Braerah et al 2020). Oleh karena itu, kebutuhan lahan pada wilayah tersebut menjadi faktor penting dalam pembangunan, sehingga kebutuhan ruang menjadi prioritas untuk meningkatkan pembangunan baik dari sektor ekonomi, infrastruktur dan lainnya maka ketersediaan lahan menjadi terbatas. Perkembangan perubahan lahan menyebabkan lahan yang sebelumya diperuntukan untuk pertanian, tambak, ruang terbuka hijau menjadi beralih fungsi menjadi tempat-tempat komersil, pusat pergadangan, maupun untuk Kawasan sosial.

Tingginya kebutuhan lahan di perkotaan menyebabkan semakin sempitnya kebutuhan manusia yang bermata pencaharian sebagai petani ketersediaan lahannya menjadi terbatas, hal ini disebabkan meningkatnya jumlah penduduk dan juga pengaruh tingginya migrasi serta mobilisasi penduduk dari daerah lain. Perubahan fungsi penggunaan lahan merupakan peraliahan dari fungsi penggunaan lahan tertentu yang sebelumnya lahan kosong maupun lahan tegalang atau lahan yang tidak difungsikan sebelumnya menjadi berubah dan beralih fungsi untuk kebutuhan manusia di bidang perumahan maupun untuk pusat bisnis dengan tujuan untuk kepentingan ekonomi setiap daerah. Hal ini disebabkan adanya desakan meningkatan kebutuhan manusia dan populasi penduduk yang tinggi.

Penggunaan lahan yang digunakan manusia dari waktu kewaktu terus mengalami perubahan seiring dengan 
perkembangan peradaban dan kebutuhan manusia karena semakin tinggi kebutuhan manusia maka semakin tinggi pula kebutuhan manusia akan lahan. Pergeseran perubahan fungsi lahan dengan perubahan tata ruang tampa memperhatikan kondisi geografis yang meliputi aspek alamiah dengan daya dukungnya dalam jangka panjang akan berdampak negatif terhadap lahan dan lingkungan, (Dwiyanti, 2013). Penurunan tingkat layanan (level of service) jalan akibat meningkatnya volume lalu lintas dan peningkatan pencemaran udara dan suara serta volume limbah cair merupakan masalah yang kemudian muncul dan mempengaruhi tingkat kenyamanan hunian di Kawasan Pallangga (Taking, 2015).

Sulawesi selatan pada umumnya dan Makassar pada khususnya sebagai salah satu kota dengan potensi wisata, bisnis dan budaya yang cukup signifikan, serta sebagai pintu gerbang kawasan timur Indonesia, sehingga menjadi suatu pertimbangan bahwa pengelolaan Bandara Sultan Hasanuddin saat ini diserahkan kepada PT. (Persero) Angkasa Pura I, PT. (Persero) Angkasa Pura I merupakan salah satu Badan Usaha Milik Negara di bawah binaan Kementrian BUMN dan Kementrian Perhubungan, yang mempunyai peran penting dalam menjembatani tugas-tugas dan wewenang sektor perhubungan terutama sub sektor perhubungan udara serta membantu pemerintah dalam mensukseskan program-program pembangunan. Salah satu bidang usaha PT. (Persero) Angkasa Pura I adalah pengelolaan Bandara yang bersifat komersial dan non komersial.

Bandar Udara Sultan Hasanuddin dalam simpul transportasi udara merupakan pusat pengembangan ekonomi khususnya pada wilayah Indonesia Timur yang sangat berdampak positif dari segi ekonomi. Jalan penghubung dan simpul utama dari pusat kota Makassar dan Bandara Sultan Hasanuddin adalah jl Pettarani, Pengaruh pembangunan Jalan Tol Layang terhadap kondisi aksesibilitas Jalan A.P.Pettarani, menunjukkan bahwa sebagian kondisi aksesibilitas dipengaruhi oleh variabel pembangunan jalan tol layang. Sedangkan secara parsial pengaruh pembangunan Jalan Tol Layang terkait pelaksanaan konstruksi, manajemen lalu lintas dan panjang jalan tol memberikan pengaruh secara signifikan terhadap kondisi aksesibilitas jalan A.P.Pettarani yang meliputi jarak tempuh, waktu tempuh, biaya transportasi, tingkat kenyamanan, tingkat keamanan dan tingkat kemudahan (Pratiwi et al, 2020) Dalam perkembangannya lima tahun terakhir Bandar Udara Sultan Hasanuddin menjadi penopang ekonomi bagi daerah lain yang ada di utara dan timur seperti Kota Manado sekitarnya serta wilayah Papua sekitarnya dan menjadi Bandar Udara yang sentral bagi pertumbuhan ekonomi di indonesia.

Pada dasarnya Bandar Udara Sultan Hasanuddin Makassar berada jauh dari pusat Kota Makassar tepatnya Kabupaten Maros, akan tetapi saat ini bandara tersebut semakin dekat dikarenakan tersedianya konektivitas yang menghubungkan antara bandara dan pusat kota. Namun melihat perkembangan Kota Makassar yang sangat pesat sehingga mengarahkan segala aktivitas kegiatan mengarah keluar perkotaan. Pada akhirnya disekitar bandara pun membentuk suatu kota tersendiri dengan segala aktivitas kegiatan untuk mendukung pelayanan dari bandara tersebut. Saat ini di sekitar bandara sedang berkembang pemukiman skala besar, perdagangan jasa seperti hotel, Kesehatan dan lain sebagainya.

Dengan melihat potensi serta isu perkembangan Bandar Udara Sultan Hasanuddin, maka akan memberikan spread effect selain kontribusi penerbangan namun juga berupa perkembangan wilayah sekitarnya dimana akan menjadi pusat ekonomi baru yang akan menstimulasi perkembangan daerah sekitar. Berdasarkan uraian diatas yang telah di kemukakan dalam penelitian ini, maka penulis tertarik untuk melakukan penelitian dengan mengangkat judul "Konsep Pengembangan Aerotropolis Di Bandara Internasional Sultan Hasanuddin Makassar".

\section{Metode Penelitian}

Jenis penelitian ini yang digunakan adalah kuantitatif. Karena dalam penelitian ini mencoba mengkaji dan menganalisa pengembangan Konsep Aerotropolis Di Bandara Internasional Sultan Hasanuddin Makassar. Penetapan sampel dilakukan berdasarkan jumlah penduduk berdasarkan hasil observasi awal yang ada pada lokasi penilitian. Karena jumlah populasi telah diketahui maka Rumus yang di pakai dalam peneliti ialah Rumus penentuan sampel Taro Yaname (Younie,2011). Jumlah sampel atau responden yakni 100 responden. Ruang lingkup wilayah penelitian ini secara makro berada di Kabupaten Maros yang berbatasan langsung dengan Kota Makassar yang merupakan Ibukota Provinsi Sulawesi Selatan. Secara mikro pada penelitian ini membahas Kecamatan Mandai serta mengenai profil singkat dari Bandara Internasional Sultan Hasanuddin Makassar serta Ruang lingkup substansi yang akan dibahas dalam penelitian ini adalah karakteristik pelayanan Bandara Internasional Sultan Hasanuddin Makassar didalam mendukung konsep aerotropolis. Sehingga konsep pengembangan aerotropolis bisa diterapkan di Bandara Internasional Sultan Hasanuddin Makassar dengan memperhatikan aspek-aspek/karakteristik yang ditemukan dalam penelitian ini. Penetuaan variabel dalam penelitian ini mengacu terhadap hasil penelitian ayuningtyas (2014) yang menentukan prinsip aerotropolis berdasarkan konsep aerotropolis yang di kembangkan oleh John D. Kasarda. Adapun variabel penelitian ini adalah Prinsip Struktur Ruang, Prinsip Jarak/Aksesibilitas, Prinsip Zonasi, Prinsip Tata Guna Lahan, Prinsip Peruntukkan Utama Fungsi Kawasan, Prinsip Penyediaan Kawasan Bisnis, Prinsip Integrasi, Prinsip Konektivitas.

Secara garis besar didalam penelitian ini menggunakan beberapa alat analisis diantaranya : Pada rumusan masalah pertama yaitu bagaimana karakteristik pelayanan Bandara Internasional Sultan Hasanuddin Makassar dalam mendukung konsep aerotropolis dilakukan analisa mendalam mengunakan metode analisis data deskriptif kuantitatif. Penggunaan metode deskriptif kuantitatif ini diselaraskan dengan variabel penelitian yang memusatkan pada masalah-masalah aktual dan fenomena yang sedang terjadi pada saat sekarang dengan bentuk hasil penelitian berupa angka-angka memiliki makna. Sebagaimana dikemukakan oleh Nana Sudjana (Sugiyono, 
2010) bahwa: "Metode penelitian deskriptif dengan pendekatan secara kuantitatif digunakan apabila bertujuan untuk mendeskripsikan atau menjelaskan peristiwa atau suatu kejadian yang terjadi pada saat sekarang dalam bentuk angka-angka yang bermakna". Adapun penelitian deskriptif dengan pendekatan kuantitatif ini adalah untuk menjelaskan suatu situasi yang hendak diteliti dengan dukungan studi kepustakaan sehingga lebih memperkuat analisa peneliti dalam membuat suatu kesimpulan. Dimana hasil penelitian diperoleh dari hasil perhitungan indikatorindikator variabel penelitian kemudian dipaparkan secara tertulis oleh penulis. Untuk pengujian secara statistik menggunakan metode statistik-kuantitatif, yaitu Data yang terjaring melalui hasil observasi di lokasi penelitian, diolah dan dianalisis dengan metode deskriptif- kuantitatif dengan menggunakan pendekatan tabulasi silang (Crosstabulation). Data yang terkumpul dilakukan kategorisasi dengan skala likert, yaitu sangat berpengaruh, berpengaruh, kurang berpengaruh, tidak berpengaruh dan sangat tidak berpengaruh. Penentuan kategorisasi didasarkan pada skala likert dalam tabel berikut:

Tabel 1 Penentuan Bobot Dengan Skala Likert

\begin{tabular}{clcc}
\hline No & \multicolumn{1}{c}{$\begin{array}{c}\text { Skala } \\
\text { Likert }\end{array}$} & Persentase (\%) & $\begin{array}{c}\text { Nilai } \\
\text { Bobot }\end{array}$ \\
\hline 1. & Sangat Berpengaruh & $88,87-100$ & 5 \\
2. & Berpengaruh & $66,67-88,88$ & 4 \\
3. & Kurang Berpengaruh & $44,45-66,66$ & 3 \\
4. & Tidak Berpengaruh & $22,23-44,44$ & 2 \\
5. & Sangat Tidak & $0,00-22,22$ & 1 \\
& Berpengaruh & & \\
\hline \multicolumn{2}{l}{ Sumber: Sugiyono, 2005 }
\end{tabular}

Pada rumusan masalah kedua yaitu bagaimana konsep pengembangan aerotropolis di Bandara Internasional Sultan Hasanuddin Makassar yakni menggunakan pendekatan Analisis path/Jalur. Ghozali (2013:249), menyatakan bahwa: "Analisis jalur merupakan perluasan dari analisis linear berganda, atau analisis jalur adalah penggunaan analisis regresi untuk menaksir hubungan kausalitas antar variabel (model kausal) yang telah ditetapkan sebelumnya berdasarkan teori”. Analisis jalur sendiri tidak menentukan hubungan sebab-akibat dan juga tidak dapat digunakan sebagai subtitusi bagi peneliti untuk melihat hubungan kausalitas antar variabel. Hubungan kausalitas antar variabel telah dibentuk dengan model berdasarkan landasan teoritis. Apa yang dilakukan oleh analisis jalur adalah menentukan pola hubungan antara tiga atau lebih variabel dan tidak dapat digunakan untuk mengkonfirmasi atau menolak hipotesis kausalitas imajiner. Dalam analisis jalur sebelum peneliti melakukan analisis suatu penelitian, terlebih dahulu peneliti membuat diagram jalur yang digunakan untuk mempresentasikan permasalahan dalam bentuk gambar dan menentukan persamaan struktural yang menyatakan hubungan antar variabel pada diagram jalur tersebut. Juliansyah Noor (206) menyatakan bahwa: "Diagram jalur dapat digunakan untuk menghitung pengaruh langsung dan tidak langsung dari variabel Independen terhadap suatu variabel dependen. Pengaruhpengaruh itu tercermin dalam apa yang disebut dengan koefisien jalur, dimana secara matematik analisis jalur mengikuti mode struktural".

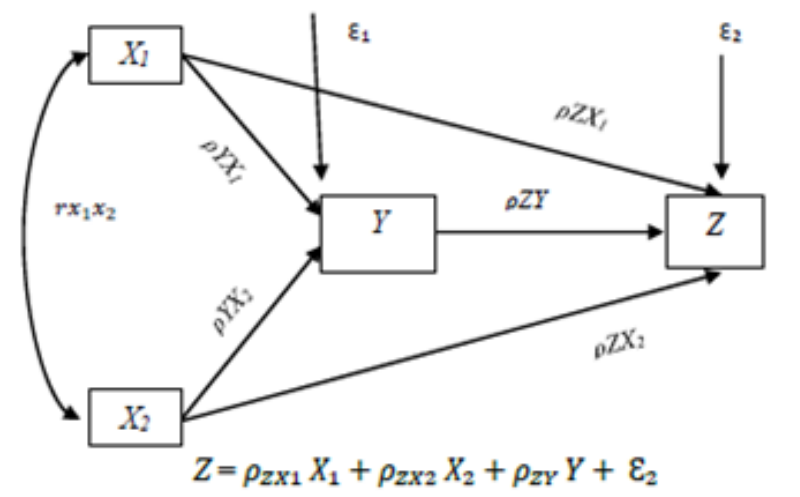

Gambar 1 Model Analisis Jalur/Path

\section{Hasil dan Pembahasan}

1. Analisis Karakteristik Pelayanan Bandara Sultan Hasanuddin

a. Prinsip Struktur Ruang

Prinsip struktur ruang yang dimaksud disini adalah hirarki sistem pusat pelayanan dimana menetapkan bandara sebagai pengembangan pusat kota baru yang berbasis pada bandar udara. Berdasarkan hasil jawaban responden bahwa pada indikator sistem pusat pelayanan pernyataan pertama yakni bandara sultan hasanuddin makassar dikembangkan sebagai pusat kota berbasis bandara, responden menjawab sangat setuju sebanyak 8 responden atau sekitar $8 \%$, setuju sebanyak 41 responden atau sekitar $41 \%$, cukup setuju sebanyak 38 responden atau sekitar $38 \%$ dan tidak setuju sebanyak 13 responden atau sekiar 13\%. Hal ini menggambarkan bahwa kota berbasis bandara akan mempengaruhi sistem ekonomi baru antara dalam negeri dan luar negeri.

Pernyataan kedua yakni perkembangan bandar udara sultan hasanuddin makassar, responden menjawab sangat berkembang sebanyak 73 responden atau $73 \%$, berkembang sebanyak 15 responden atau sekitar $15 \%$ dan cukup berkembang sebanyak 12 responden atau $12 \%$. Hal ini menunjukan bahwa perkembangan bandar udara sultan hasanuddin telah mengalami perkembangan dikarenakan menjadi salah satu hub penerbangan yang ada diindonesia untuk melayani bagian wilayah Indonesia timur khususnya. b. Prinsip Jarak/Aksesibilitas

Prinsip Jarak/Aksesibilitas yang dimaksud disini berdasarkan indikator yang diukur adalah rute pelayanan, jangkauan pelayanan serta waktu dan biaya. Berdasarkan hasil jawaban responden bahwa pada indikator rute pelayanan pernyataan pertama yakni Sejauh Ini Rute Pelayanan Penerbangan Sudah Banyak Tersedia Di Bandar Udara Sultan Hasanuddin, responden menjawab sangat mudah sebanyak 61 responden atau sekitar $61 \%$, mudah sebanyak 23 responden atau sekitar $23 \%$ dan cukup mudah sebanyak 16 responden atau sekitar 16\%. Hal ini menggambarkan bahwa karakteristik rute pelayanan penerbangan di bandar udara sultan hasanuddin mudah tersedia karena sudah terhubung dengan bandara-bandara lokal dan internasional. Pernyataan kedua yakni rute penerbangan yang anda inginkan sudah tersedia, responden menjawab sangat mudah sebanyak 24 responden atau $24 \%$, mudah sebanyak 53 responden atau sekitar 53\% dan cukup 
mudah sebanyak 23 responden atau 23\%. Hal ini menunjukan bahwa masyarakat saat ini sudah terbantukan oleh keberadaan bandara udara sultan hasanuddin makassar sebagai penghubung asal dan tujuan masyarakat.

Pada indikator jangkauan pelayanan dengan pernyataan tersebut yakni frekuensi terhadap jangkauan pelayanan penerbangan bandara melayani penerbangan domestik dan internasional, responden menjawab sangat mendukung sebanyak 65 responden atau sekitar 65\%, mendukung sebanyak 32 responden atau sekitar $32 \%$ dan cukup mendukung sebanyak 3 responden atau sekitar $3 \%$. Hal ini menggambarkan bahwa karakteristik jangkauan pelayanan penerbangan di bandar udara sultan hasanuddin sangat mendukung mobilitas pergerakan orang ataupun barang sehingga akan berpengaruh terhadap kondisi ekonomi dan sebagainya.

c. Prinsip Zonasi

Prinsip Zonasi yang dimaksud disini berdasarkan indikator yang diukur adalah tingkat kepadatan penduduk serta ketinggian bangunan. Berdasarkan hasil jawaban responden bahwa pada indikator tingkat kepadatan penduduk dengan pernyataan tersebut yakni Tingkat Kepadatan Penduduk Disekitar Anda, responden menjawab sangat berkembang sebanyak 24 responden atau sekitar $24 \%$, berkembang sebanyak 58 responden atau sekitar $58 \%$ dan cukup berkembang sebanyak 18 responden atau sekitar $18 \%$. Hal ini menggambarkan bahwa karakteristik tingkat kepadatan penduduk pada sekitar bandar udara sultan hasanuddin telah mengalami peningkatan dari tahun ke tahun.

Pada indikator Ketinggian Bangunan dengan pernyataan tersebut yakni Ketinggian Banggunan Disekitar Bandara Telah Mempertimbangkan KKOP Bandara., responden menjawab sangat setuju sebanyak 40 responden atau sekitar $40 \%$, setuju sebanyak 51 responden atau sekitar $51 \%$ dan cukup setuju sebanyak 9 responden atau sekitar 9\%. Hal ini menggambarkan bahwa karakteristik ketinggian bangunan disekitar bandara telah memenuhi syarat KKOP karena akan sangat berpengaruh terhadap pontesi bahaya pada penerbangan dan lainnya.

d. Prinsip Tata Guna Lahan

Prinsip Tata Guna Lahan yang dimaksud disini berdasarkan indikator yang diukur adalah harga lahan, nilai lahan, intensitas penggunaan lahan serta karakteristik fisik lahan. Berdasarkan hasil jawaban responden bahwa pada indikator harga lahan dengan pernyataan tersebut yakni Harga Lahan Pada Sekitar Bandara Telah Mengalami Peningkatan, responden menjawab sangat setuju sebanyak 17 responden atau sekitar 17\%, setuju sebanyak 56 responden atau sekitar $56 \%$ dan cukup setuju sebanyak 27 responden atau sekitar $27 \%$. Hal ini menggambarkan bahwa karakteristik harga lahan disekitar bandara telah mengalami peningkatan akibat perkembangan perkotaan.

Pada indikator nilai lahan pernyataan pertama yakni Jika Penerapan Konsep Aetropolis Dilaksanakan Maka Nilai Jual Lahan Akan Meningkat, responden menjawab sangat setuju sebanyak 24 responden atau sekitar $24 \%$, setuju sebanyak 58 responden atau sekitar 58\% dan cukup setuju sebanyak 18 responden atau sekitar $18 \%$. Hal ini menggambarkan bahwa karakteristik nilai lahan jika konsep aerotropolis diterapkan akan mengalami peningkatan karena segala aktivitas kegiatan akan berpusat pada bandar udara dan berpengaruh pada daerah sekitarnya. Pernyataan kedua yakni apakah anda akan menjual lahan Anda responden menjawab sangat setuju sebanyak 7 responden atau $7 \%$, setuju sebanyak 28 responden atau sekitar $28 \%$ dan cukup setuju sebanyak 38 responden atau $38 \%$ dan tidak setuju sebanyak 27 responden atau sekitar $27 \%$. Hal ini menunjukan bahwa karakteristik lahan akan sangat berpengaruh terhadap pembangunan bandar udara yang mengarah kekonsep aerotropolis.

Sedangkan indikator Intensitas Penggunaan Lahan pernyataan pertama yakni Seberapa Sering Intensitas Penggunan Lahan Berubah Fungsi Dari Kawasan Pertanian Menjadi Lahan Terbangun, responden menjawab sangat sering sebanyak 46 responden atau sekitar $46 \%$, sering sebanyak 39 responden atau sekitar 39\% dan cukup sering sebanyak 15 responden atau sekitar $15 \%$. Pernyataan kedua yakni Tentang Fenomena Intensitas Perubahan Penggunaan Lahan Tersebut responden menjawab sangat setuju sebanyak 42 responden atau $42 \%$, setuju sebanyak 36 responden atau sekitar $36 \%$ dan cukup setuju sebanyak 22 responden atau 22\%. Hal ini menggambarkan bahwa karakteristik intensitas penggunan lahan berubah fungsi dari kawasan pertanian menjadi lahan terbangun adalah akibat jumlah penduduk yang semakin bertambah serta ruang yang tidak mengalami perubahan. Keberadaan bandar udara sangat mempengaruhi aktivitas intensitas penggunaan lahan.

Serta indikator Karakteristik Fisik Lahan pernyataan pertama yakni Karakteristik Fisik Lahan Disekitar Bandar Udara Sultan Hasanuddin., responden menjawab sangat baik sebanyak 27 responden atau sekitar 27\%, baik sebanyak 62 responden atau sekitar $62 \%$ dan cukup mendukung sebanyak 11 responden atau sekitar $11 \%$. Hal ini menggambarkan bahwa karakteristik Fisik Lahan disekitar bandara dapat dikembangkan dengan baik karena masih memiliki lahan yang masih kosong.

e. Prinsip Peruntukan Utama Fungsi Kawasan, Prinsip

Penyediaan Kawasan Bisnis

Prinsip Peruntukkan Utama Fungsi Kawasan \& Prinsip Penyediaan Kawasan Bisnis yang dimaksud disini berdasarkan indikator yang diukur adalah Ketersediaan Fasilitas Perdagangan Dan Jasa. Berdasarkan hasil jawaban responden bahwa pada indikator Ketersediaan Fasilitas Perdagangan Dan Jasa pernyataan pertama yakni pembangunan fasilitas perdagangan dan jasa yang ada dibandara dan sekitarnya, responden menjawab sangat mendukung sebanyak 9 responden atau sekitar 9\%, mendukung sebanyak 69 responden atau sekitar $69 \%$ dan cukup mendukung sebanyak 22 responden atau sekitar $22 \%$. Pernyataan kedua yakni penerapan aerotropolis dibandara sultan hasanuddin akan menyediakan fasilitas perdagangan dan jasa responden menjawab sangat setuju sebanyak 71 responden atau $71 \%$, setuju sebanyak 25 responden atau sekitar $25 \%$ dan cukup setuju sebanyak 4 responden atau 4\%. Hal ini menggambarkan bahwa Ketersediaan Fasilitas Perdagangan Dan Jasa akan sangat mendukung kegiatan ekonomi disekitar bandara.

f. Prinsip Integrasi, Prinsip Konektivitas

Prinsip Integrasi \& Prinsip Konektivitas yang dimaksud disini berdasarkan indikator yang diukur adalah 
Ketersediaan Jaringan Jalan, Ketersediaan Fasilitas Sosial Dan Fasilitas Umum dan Ketersediaan Moda Transportasi. Berdasarkan hasil jawaban responden bahwa pada indikator Ketersediaan Jaringan Jalan pernyataan pertama yakni Kondisi Jaringan Jalan Yang Tersedia Untuk Menghubungkan Bandar Udara Dengan Asal Anda, responden menjawab sangat baik sebanyak 78 responden atau sekitar $78 \%$, baik sebanyak 20 responden atau sekitar $20 \%$ dan cukup baik sebanyak 2 responden atau sekitar $2 \%$. Hal ini menggambarkan bahwa Ketersediaan Jaringan Jalan sudah sangat baik. Perlunya penambahan agar dapat mempercepat mobilitas untuk menggunakan jasa transportasi udara.

Pada indikator Ketersediaan Fasilitas Sosial Dan Fasilitas Umum pernyataan pertama yakni Ketersediaan Fasilitas Sosial Dan Fasilitas Umum Yang Ada Dibandara Dan Sekitarnya, responden menjawab sangat mendukung sebanyak 65 responden atau sekitar 65\%, mendukung sebanyak 24 responden atau sekitar $24 \%$ dan mendukung sebanyak 11 responden atau sekitar $11 \%$. Hal ini menggambarkan bahwa diperlukan Ketersediaan Fasilitas Sosial Dan Fasilitas Umum Yang Ada Dibandara.

Sedangkan pada indikator Ketersediaan Moda Transportasi pernyataan pertama yakni Ketersediaan Moda Transportasi Dibandar Udara Serta Untuk Menghubungkan Tempat Asal Anda, responden menjawab sangat Mudah sebanyak 82 responden atau sekitar $82 \%$, Mudah sebanyak 12 responden atau sekitar $12 \%$ dan cukup mudah sebanyak 6 responden atau sekitar 6. Hal ini menggambarkan bahwa Ketersediaan Moda Transportasi sangat mudah dijumpai untuk menuju bandar udara.

Berdasarkan hasil rekapitulasi dari hasil analisis beberapa indikator yang telah dijabarkan pada Tabel 2 dapat ditarik kesimpulan, bahwa karakteristik pelayanan Bandara Sultan Hasanuddin Makassar didalam mendukung konsep pengembangan aerotropolis dipengaruhi oleh Hirarki Sistem Pusat Pelayanan, Rute Pelayanan, Jangkauan Pelayanan, Waktu Dan Biaya, Tingkat Kepadatan Penduduk, Ketinggian Bangunan, Harga Lahan, Nilai Lahan, Intensitas Penggunaan Lahan, Karakteristik Fisik Lahan, Ketersediaan Fasilitas Perdagangan Dan Jasa, Ketersediaan Jaringan Jalan, Ketersediaan Fasilitas Sosial Dan Fasilitas Umum dan Ketersediaan Moda Transportasi.

Perkembangan Bandara Sultan Hasanuddin saat ini telah mengalami perubahan dikarenakan bandara tersebut menjadi bandara east internasional hub yang dapat melayani wilayah timur indonesia dan mancanegara. Kondisi ini secara spesifik bandara sultan hasanuddin memungkinkan dikembangkan menjadi konsep aerotropolis. Akan tetapi, untuk membentuk sebuah aerotropolis maka bandara harus siap dari segala infrastrukturnya, jika dimungkinkan untuk mengembangkan konsep aerotropolis maka terlebih dahulu bandara sultan hasanuddin makassar harus dijadikan sebagai pengembangan bandara aerocity untuk menyediakan segala kebutuhan seperti pusat belanja yang nantinya menjadi penggerak utama sektor ekonomi yang akan berdampak pada wilayah sekitar dan aktivitas lainnya untuk menuju pengembangan konsep aerotropolis.

Sejalan dengan teori Arthur dan Simon (1963), pusat kota adalah pusat keruangan dan administrasi dari wilayahnya dikatakan bahwa Pusat kota merupakan tempat dari generasi ke generasi menyaksikan perubahanperubahan waktu, Pusat kota merupakan tempat vitalitas kota memperoleh makanan dan energi, dengan tersebarnya pusat-pusat aktivitas seperti pemerintahan, lokasi untuk balai kota, toko-toko besar, dan bioskop, Pusat kota merupakan tempat kemana orang pergi bekerja, tempat ke mana mereka "pergi ke luar", Pusat kota merupakan terminal dari pusat jaringan, jalan kereta api, dan kendaraan umum, Pusat kota merupakan kawasan di mana kita menemukan kegiatan usaha, kantor pemerintahan, pelayanan, gudang dan industri pengolahan, pusat lapangan kerja, wilayah ekonomis metropolitan, Pusat kota merupakan penghasilan pajak yang utama, meskipun kecil namun nilai bangunan yang ada di pusat kota merupakan proporsi yang besar dari segala keseluruhan kota, karena pusat kota memiliki prasarana yang diperlukan untuk pertumbuhan ekonomi, Pusat kota merupakan pusat-pusat fungsi administratif dan perdagangan besar, mengandung rangkaian toko-toko eceran, kantor-kantor profesional, perusahaan jasa, gedung bioskop, cabang-cabang bank dan bursa saham. Dalam kota kecil yang swasembada, kawasan ini juga menyediakan fasilitas perdagangan besar mencakup pusat-pusat administratif dan transportasi yang diperlukan.

Berdasarkan hasil pengamatan saat ini bandara sultan hasanuddin mengalami perubahan ini dipengaruhi oleh adanya permintaan sehingga bandara tersebut melakukan perubahan untuk menampung kapasitas dibandara. Rute pelayanan hingga jangkauan pelayanan terhadap bandara sangat berpengaruh didalam perubahan fisik bandara. Oleh karena itu, penyiapan infastruktur dasar didalam pembangunan bandara harus disiapkan selebih mungkin seperti jalan dan lainnya.

2. Konsep Pengembangan Aerotropolis Di Bandara Internasional Sultan Hasanuddin Makassar

Untuk menjawab rumusan masalah kedua yakni Pada konsep pengembangan aertropolis di Bandara Internasional Sultan Hasanuddin Makassar dengan melihat variabel karakteristik aerotropolis dengan menggunakan analisis Path/Jalur. Berikut hasil pengujian analisis Path/Jalur tentang bagaimana konsep pengembangan konsep aerotropolis dibandara internasional sultan hasanuddin. Dari hasil analisis ini berdasarkan variabel maka akan dilihat hasil yang paling berpengaruh langsung dan tidak langsung secara signifikan terhadap pembentukan konsep aerotropolis.

Tabel 3. Uji Hipotesis Regression Weights: (Group number 1 - Default model)

\begin{tabular}{|c|c|c|c|c|c|c|}
\hline & & Estimate & S.E. & C.R. & & Label \\
\hline BANDARA & $<---$ PJA &,- 152 & 255 &,- 594 &, 552 & par_1 \\
\hline BANDARA & $<---\quad P Z$ & 279 &, 145 & 1,921 &, 055 & par_2 \\
\hline BANDARA & $<---$ PTGL &, 144 & 240 &, 598 &, 550 & par_3 \\
\hline BANDARA & $<---$ PUFK &, 091 &, 135 & .673 &, 501 & par_5 \\
\hline BANDARA & $<---$ PIK &,- 482 & 204 & $-2,362$ &, 018 & par_6 \\
\hline BANDARA & $<---$ PSR &,- 255 &, 136 & $-1,869$ &, 062 & par_7 \\
\hline AEROTROPOLIS & $<---$ BANDARA & 421 &, 117 & 3,586 & $* * *$ & par_4 \\
\hline
\end{tabular}

Keterangan : dinyatakan terdapat pengaruh jika nilai $\mathrm{P}>0,05) / 5 \%$

Tabel 4. Standardized Regression Weights: (Group number 1 - Default model)

Estimate S.E. C.R.

PLabel

\begin{tabular}{|c|c|c|c|c|c|c|}
\hline & & 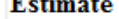 & . & 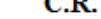 & \multirow{4}{*}{\multicolumn{2}{|c|}{$\begin{array}{l}881 \\
, 147 \\
, 054\end{array}$}} \\
\hline PJA & $<-->P Z$ &, 002 &, 013 &, 150 & & \\
\hline PJA & $<->$ PTGL &,- 013 & .009 & $-1,450$ & & \\
\hline PJA & $<->$ PSR &,- 030 & .016 & $-1,927$ & & \\
\hline PJA & <--> PUFK &,- 018 & .015 & $-1,237$ &, 216 & par_11 \\
\hline PJA & $<-->$ PIK & .017 &, 010 & 1,720 &, 085 & par_12 \\
\hline $\mathrm{PZ}$ & $<->$ PTGL & 033 &, 015 & 2,111 &, 035 & par_13 \\
\hline
\end{tabular}


Tabel 5. Covariances: (Group number 1 - Default model)

\begin{tabular}{|c|c|c|}
\hline & & Estimate \\
\hline BANDARA & $<---$ PJA &,- 061 \\
\hline BANDARA & $<---\quad P Z$ & ,191 \\
\hline BANDARA & $<---$ PTGL &, 065 \\
\hline BANDARA & $<---$ PUFK &, 068 \\
\hline BANDARA & $<---$ PIK &,- 239 \\
\hline BANDARA & $<---$ PSR &,- 200 \\
\hline AEROTROPOLIS & $<---$ BANDARA &, 339 \\
\hline
\end{tabular}

Tabel 6. Correlations: (Group number 1 - Default model)

\begin{tabular}{|l|r|r|}
\hline & & Estimate \\
\hline PJA & $<->$ PZ &, 015 \\
\hline PJA & $<->$ PTGL &,- 147 \\
\hline PJA & $<->$ PSR &,- 197 \\
PJA & $<->$ PUFK &,- 125 \\
\hline PJA & $<->$ PIK &, 176 \\
PZ & $<->$ PTGL &, 217 \\
PZ & $<->$ PSR &, 097 \\
PZ & $<->$ PUFK &,- 049 \\
PZ & $<->$ PIK &, 078 \\
PTGL & $<->$ PSR &,- 292 \\
PTGL & $<->$ PUFK &,- 165 \\
PTGL $<->>$ PIK &, 000 \\
PUFK $<-->$ PSR &,- 064 \\
PIK & $<->$ PSR &,- 222 \\
PUFK $<-->$ PIK &, 211 \\
\hline
\end{tabular}

Tabel 7. Squared Multiple Correlations: (Group number 1 Default model)

\begin{tabular}{|l|c|}
\hline & Estimate \\
\hline BANDARA &, 117 \\
\hline AEROTROPOLIS &, 115 \\
\hline
\end{tabular}

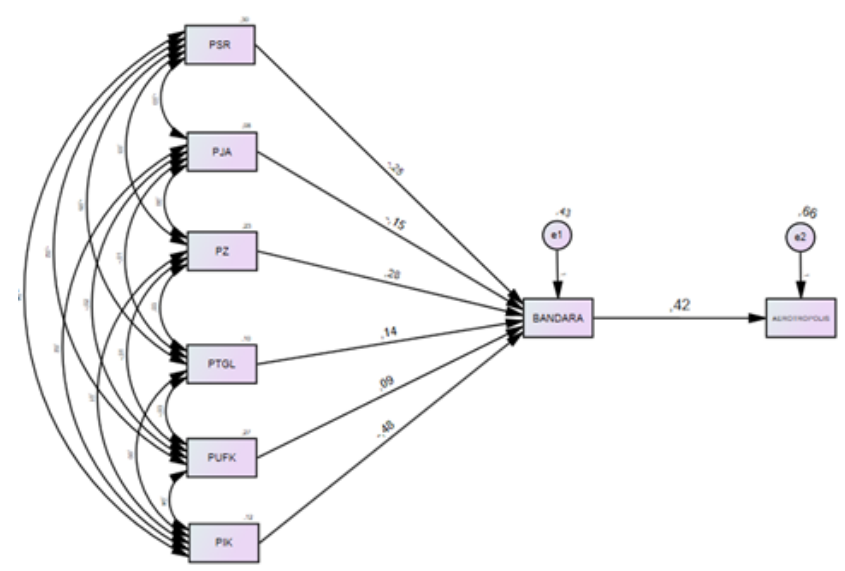

Gambar 2 Model Analisis Path/Jalur

Berdasarkan hasil analisa menggunakan analisis path/jalur didalam penelitian ini secara metode uji sobel maka dilakukan analisa untuk mencari nilai $\mathrm{z}$ dengan melakukan analisa pengaruh secara langsung maupun tidak langsung. Hasil analisa tersebut dapat dilihat pada Tabel 3.

Berdasarkan hasil tabulasi diatas sesuai formulasi perhitungan Kristopher J. Preacher dikatakan Nilai-p yang dilaporkan (dibulatkan ke 8 tempat desimal) diambil dari distribusi normal unit dengan asumsi uji-z dua arah dari hipotesis bahwa efek yang dimediasi sama dengan nol dalam populasi. +/- 1,96 adalah nilai kritis dari rasio uji yang berisi $95 \%$ pusat distribusi normal unit. Artinya bahwa nilai $\mathrm{z}$ atau dikatakan signifikan jika nilai z sobelnya lebih dari 1,96.

Dari hasil analisis jalur diatas secara langsung mengindikasikan bahwa berdasarkan varibel yang telah ditentukan memiliki dampak positif dan negatif. Karakteristik pelayanan yang memiliki dampak positif yakni Prinsip Zonasi Terhadap Bandara dengan koefisien jalur sekitar 0,279 masih berpengaruh positif, artinya bahwa saat ini tingkat kepadatan penduduk maupun ketinggian bangunan disekitar bandara masih sesuai aturan KKOP yang telah dibuat. Untuk Prinsip Tata Guna Lahan Terhadap Bandara masih berpengaruh positif dengan koefisien jalur sekitar 0,144 ini diartikan bahwa saat ini untuk pengembangan konsep bandara menuju aerocity menjadi aeroropolis masih dapat dilaksanakan dengan bandara sebagai pusat pelayanan perkotaan karena masih terdapat lahan yang tersedia dengan memperhatikan hakhak guna lahan masyarakat sekitarnya. Perubahan pemanfaatan lahan nantinya harus mengikuti peraturan yang sudah dibuat seperti harus sesuai dengan rencana tata ruang, Untuk Peruntukan Fungsi Kawasan Terhadap Bandara masih berpengaruh positif dengan koefisien jalur sekitar 0,091. Artinya bahwa penyiapan ketersediaan fasilitas perdagangan dan jasa dibandara sangat penting dilaksanakan agar kegiatan ekonomi dapat berpusat dibandara untuk mendorong pertumbuhan ekonomi disekitarnya. Sehingga percepatan pembangunan bandara ke Aerocity untuk memajukan perekenomian daerah. Karakteristik pelayanan yang berdampak negatif yakni karakteristik pelayanan prinsip jarak/aksesibilitas dengan koefisien jalur -0,152, artinya bahwa rute pelayanan, jangkaun pelayanan serta waktu dan biaya menentukan 
suksesnya pengembangan Kearah konsep aerotropolis. Bandara sebagai tujuan dan datangnya barang/manusia dengan mengedepankan nilai ekonomi, sosial dan budaya. Untuk Prinsip Intergrasi Dan Konektivitas berpengaruh negatif secara langsung dengan koefisien jalur -0,482. Artinya bahwa didalam pengembangan bandara keaerocity menuju konsep aerotropolis agar dapat didukung dengan penyediaan jaringan transportasi antar moda yang saling terhubung baik darat, udara dan rel kereta api. Penciptaan jaringan antar moda terintegrasi untuk menjamin keterhubungan antar pusat-pusat kegiatan/pelayanan dalam lingkup internal Kawasan ataupun dengan pusat pelayanan melalu integrasi antar moda untuk menciptakan kemudahan mobilitas orang dna barang tanpa hambatan. Untuk Prinsip Struktur Ruang Terhadap Aerotropolis berpengaruh negatif dengan koefisien jalur -0,255. Artinya bahwa untuk menjalankan konsep aerotropolis terlebih dahulu untuk menempatkan wilayah tersebut sebagai sub pusat pelayanan perkotaan tertinggi. Agar segala aktivitas kegiatannya dapat menunjang aktivitas kegiatan bandar udara keaerocity menuju konsep aerotropolis.

Dalam analisis jalur/path tidak dapat menghitung pengaruh yang berdampak secara tidak langsung. Artinya butuh pengujian analisis terlebih lagi dengan menggunakan metode yang dikeluarkan oleh Kristopher J. Preacher agar dapat menghitung nilai z sobelnya. Keluaran dari analisa ini untuk mengetahui pengaruh karakteristik pelayanan secara tidak langsung berpengaruh signifikan terhadap konsep aerotropolis melalui pengembangan bandara. Dari hasil nilai $\mathrm{z}$ sobelnya diketahui pengaruh secara tidak langsung yang berpengaruh signifikan terhadap konsep aerotropolis yakni prinsip integrasi dan konektivitas. Artinya bahwa dalam pengembangan konsep aerotropolis di Bandar Udara Internasional Hasanuddin Makassar butuh penyiapan infrastuktur dasar didalam pengembangannya.

Beberapa karakteristik pelayanan yang mempengaruhi bandara dalam mendukung Konsep Aerotropolis adalah :

a. Prinsip Struktur Ruang : prinsip struktur ruang berpengaruh didalam pengembangan bandara menuju konsep aerotropolis. Dikarenakan untuk menetapkan sebagai pusat pelayanan kota harus menetapkan wilayah tersebut sebagai hirarki sistem pusat pelayanan tertinggi.

b. Prinsip Jarak/Aksesibilitas : prinsip jarak/aksesibilitas berpengaruh didalam pengembangan bandara menuju konsep aerotropolis. Hal ini sejalan dengan konsep teori Babcock 1932, bahwa Poros transportasi sangat mempengaruhi mobilitas yang menghubungkan daerah yang satu dengan daerah lainnya

c. Prinsip Zonasi : Prinsip zonasi berpengaruh didalam pengembangan bandara menuju konsep aerotropolis. Oleh karena itu didalam pembangunan disekitarnya agar dapat dijalankan sesuai aturan KKOP di Bandara Sultan Hasanuddin Makassar.

d. Prinsip Tata Guna Lahan : Prinsip Tata Guna Lahan berpengaruh didalam pengembangan bandara menuju konsep aerotropolis. Pengembangan menuju konsep aerotropolis akan semakin tak terkendali seiring dengan semakin berkembanganya penduduk. Sehingga perlu memperhatikan pertambahan penduduk sebagai salah satu faktor yang mempengaruhi ketersediaan lahan.

e. Prinsip Peruntukkan Utama Fungsi Kawasan dan Prinsip Penyediaan Kawasan Bisnis: Prinsip
Peruntukkan Utama Fungsi Kawasan dan Prinsip Penyediaan Kawasan Bisnis berpengaruh didalam pengembangan bandara menuju konsep aerotropolis. Saat ini pengembangan bisnis non aero sangat menjanjikan didalam meningkatkan pertumbuhan ekonomi.

f. Prinsip Integrasi dan Prinsip Konektivitas : Prinsip Integrasi dan Prinsip Konektivitas berpengaruh didalam pengembangan bandara menuju konsep aerotropolis. Penyiapan infrastruktur dasar ketersediaan moda transportasi penting untuk konektivitas sebagai simpul jaringan untuk meningkatkan pertumbuhan ekonomi.

Dari hasil analisis jalur diatas secara langsung mengindikasikan bahwa berdasarkan varibael yang telah ditentukan memiliki dampak positif dan negatif. Karakteristik pelayanan yang memiliki dampak positif yakni Prinsip Zonasi Terhadap Bandara dengan koefisien jalur sekitar 0,279 masih berpengaruh positif, artinya bahwa saat ini tingkat kepadatan penduduk maupun ketinggian bangunan disekitar bandara masih sesuai aturan KKOP yang telah dibuat. Untuk Prinsip Tata Guna Lahan Terhadap Bandara masih berpengaruh positif dengan koefisien jalur sekitar 0,144 ini diartikan bahwa saat ini untuk pengembangan konsep bandara menuju aerocity menjadi aeroropolis masih dapat dilaksanakan dengan bandara sebagai pusat pelayanan perkotaan karena masih terdapat lahan yang tersedia dengan memperhatikan hakhak guna lahan masyarakat sekitarnya. Perubahan pemanfaatan lahan nantinya harus mengikuti peraturan yang sudah dibuat seperti harus sesuai dengan rencana tata ruang, Untuk Peruntukan Fungsi Kawasan Terhadap Bandara masih berpengaruh positif dengan koefisien jalur sekitar 0,091. Artinya bahwa penyiapan ketersediaan fasilitas perdagangan dan jasa dibandara sangat penting dilaksanakan agar kegiatan ekonomi dapat berpusat dibandara untuk mendorong pertumbuhan ekonomi disekitarnya. Sehingga percepatan pembangunan bandara ke Aerocity untuk memajukan perekenomian daerah. Karakteristik pelayanan yang berdampak negatif yakni karakteristik pelayanan prinsip jarak/aksesibilitas dengan koefisien jalur -0,152, artinya bahwa rute pelayanan, jangkaun pelayanan serta waktu dan biaya menentukan suksesnya pengembangan Kearah konsep aerotropolis. Bandara sebagai tujuan dan datangnya barang/manusia dengan mengedepankan nilai ekonomi, sosial dan budaya. Untuk Prinsip Intergrasi Dan Konektivitas berpengaruh negatif secara langsung dengan koefisien jalur -0,482. Artinya bahwa didalam pengembangan bandara keaerocity menuju konsep aerotropolis agar dapat didukung dengan penyediaan jaringan transportasi antar moda yang saling terhubung baik darat, udara dan rel kereta api. Penciptaan jaringan antar moda terintegrasi untuk menjamin keterhubungan antar pusat-pusat kegiatan/pelayanan dalam lingkup internal Kawasan ataupun dengan pusat pelayanan melalu integrasi antar moda untuk menciptakan kemudahan mobilitas orang dna barang tanpa hambatan. Untuk Prinsip Struktur Ruang Terhadap Aerotropolis berpengaruh negatif dengan koefisien jalur -0,255. Artinya bahwa untuk menjalankan konsep aerotropolis terlebih dahulu untuk menempatkan wilayah tersebut sebagai sub pusat pelayanan perkotaan tertinggi. Agar segala aktivitas kegiatannya dapat menunjang aktivitas kegiatan bandar udara keaerocity menuju konsep aerotropolis. 
Dalam analisis jalur/path tidak dapat menghitung pengaruh yang berdampak secara tidak langsung. Artinya butuh pengujian analisis terlebih lagi dengan menggunakan metode yang dikeluarkan oleh Kristopher J. Preacher agar dapat menghitung nilai z sobelnya. Keluaran dari analisa ini untuk mengetahui pengaruh karakteristik pelayanan secara tidak langsung berpengaruh signifikan terhadap konsep aerotropolis melalui pengembangan bandara. Dari hasil nilai $\mathrm{z}$ sobelnya diketahui pengaruh secara tidak langsung yang berpengaruh signifikan terhadap konsep aerotropolis yakni prinsip integrasi dan konektivitas. Artinya bahwa dalam pengembangan konsep aerotropolis di Bandar Udara Internasional Hasanuddin Makassar butuh penyiapan infrastuktur dasar didalam pengembangannya.

\section{Kesimpulan dan Saran}

Hasil penelitian dapat disimpulkan bahwa perkembangan Bandara Sultan Hasanuddin Makassar semakin meningkat dikarenakan aktivitas yang menggunakan jasa transportasi udara meningkat masuk atau keluar di kota makassar dan sekitarnya. Hal ini ditandai dengan pembangunan kapasitas bandara sultan hasanuddin yang sampai saat ini telah dilaksanakan pembangunannya. Beberapa karakteristik pelayanan bandara yang dapat mempengaruhi bandara didalam mendukung konsep aerotropolis yakni hirarki sistem pusat pelayanan, rute pelayanan, jangkauan pelayanan, waktu dan biaya, ketinggian kepadatan penduduk, ketinggian bangunan, harga lahan, nilai lahan, intensitas penggunaan lahan, karakteristik fisik lahan, ketersediaan fasilitas perdagangan dan jasa, ketersediaan jaringan jalan, ketersediaan fasilitas sosial dan fasilitas umum dan ketersediaan moda transportasi. Pada dasarnya semua karakteristik pelayanan aerotropolis berpengaruh jika dikembangkan di bandara internasional sultan hasanuddin. Yang paling berpengaruh didalam karakteristik pelayanan bandara yakni jangkauan pelayanan, waktu dan biaya, ketersediaan fasilitas perdagangan dan jasa, ketersediaan jaringan jalan, ketersediaan fasilitas sosial/fasilitas umun dan ketersediaan moda transportasi. Sehingga didalam penerapan aerotropolis di Bandara Sultan Hasanuddin agar mempertimbangkan karakteristik pelayanan tersebut. Pengembangan konsep aerotropolis berdasarkan karakteristik pelayanan dapat dilakukan di Bandara Sultan Hasanuddin Makassar dengan melakukan pengembangan terhadap prinsip integrasi dan konektivitas yang berarti ketersediaan moda transportasi, ketersediaan jalan dan fasilitas sosial/umum yang perlu dilakukan pengembangan awal. Karena prinsip inilah yang sangat signifikan secara tidak langsung di Bandara Sultan Hasanuddin Makassar merupakan infrastruktur dasar didalam pembangunan bandara didalam pengembangan aerocity menuju konsep pengembangan aerotropolis.

\section{Daftar Pustaka}

Adisasmita, Rahardjo. (2011). Manajemen Pemerintah Daerah. Yogyakarta: Penerbit Graha Ilmu.

Ayuningtyas., \& Yonanda, R. (2014). Prinsip Perencanaan Aerotropolis. Tesis S2 Magister
Perencanaan Kota dan Daerah. Yogyakarta. Universitas Gadjah Mada.

Buraerah, M. F., Rasyidi, E. S., \& Sandi, R. (2020). Pemetaan Perubahan Penggunaan Lahan Di Wilayah Kabupaten Takalar Tahun 1999-2019 Menggunakan Sistem Informasi Geografis. Ecosystem, 20(1).

Dwiyanti, 2013. Kajian Perkembangan Guna Lahan terkait dengan perdagangan dan industri batik di desa Trusmi Kulon, Plered, Kabupaten Cirebon. Jurnal ruang volume 1 Nomor 2 Tahun 2013. Fakultas Tehnik Universitas Diponegoro. Semarang.

Gallion, Arthur B. and Simon Eisner, The Urban Pattern; City Planning and Design, D. Van Nostrand Company Inc., Canada, 1963.

Ghozali, Imam. 2013. Aplikasi Analisis Multivariate dengan Program IBM SPSS 21 Update PLS Regresi. Semarang: Badan Penerbit Universitas Diponegoro.

Kasarda, J. D. (2008). The Evolution of Airport Cities and the Aerotropolis.. London: Insight Media.

Kasarda, J. (2013). Airport cities : The evolution. Paper Report, (May), 24-27.

Kasarda, J. D. (2016). Aerotropolis. West Sussex UK: John Wiley \& Sons Press, 1-8.

MI, Taking. (2015). Perubahan Pemanfaatan Lahan dan Implikasinya dalam Pengendaliaan Ruang di Kawasan Perkotaan Sungguminasa. Universitas Bosowa.

Noor, Juliansyah, 2016. Metodelogi Penelitian. Jakarta : Kencana Prenada Media. Group. Panjika 2000. Alfabeta.

Pratiwi, A., Manaf, M., \& Aksa, K. (2020). Pengaruh Pembangunan Jalan Tol Layang Terhadap Kondisi Aksesibiltas Jalan A.P Pettarani . Journal of Urban Planning Studies, 1(1), 050-060. Diambil dari https://ejournalfakultasteknikunibos.id/index.php/j ups/article/view/17

Sugiyono, 2010, Metode Penelitian Kualitatif, Kuantitatif, dan R\&D, Bandung: Alfabeta

Surya, B., Hadijah, H., Suriani, S., Baharuddin, B., Fitriyah, A. T., Menne, F., \& Rasyidi, E. S. (2020). Spatial Transformation of a New City in 20062020: Perspectives on the Spatial Dynamics, Environmental Quality Degradation, and SocioEconomic Sustainability of Local Communities in Makassar City, Indonesia. Land, 9(9), 324.

Younie. 2011. Metode Penelitian. https://virtualyuni.wordpress.com/2011/03/08/chap ter-4- metodepenelitian/ Diakses pada 9 Oktober 2020

Yunus, H.S. 1994. Teori dan Model Struktur Keruangan Kota. Fakultas Geografi UGM. Yogyakarta. 
Tabel 2 Hasil Rekapitulasi Karakteristik Pelayanan Bandara

\begin{tabular}{|c|c|c|c|c|c|c|}
\hline No & $\begin{array}{c}\text { Karakteristik } \\
\text { Pelayanan }\end{array}$ & $\begin{array}{c}\text { Indikator Penelitian Yang } \\
\text { Diukur }\end{array}$ & $\begin{array}{l}\text { Standar Nilai } \\
\text { Pengaruh }(\%)\end{array}$ & $\begin{array}{c}\text { Nilai Hasil } \\
\text { Crosstab }(\%)\end{array}$ & Bobot & Kesimpulan \\
\hline 1 & $\begin{array}{l}\text { Prinsip Struktur } \\
\text { Ruang }\end{array}$ & $\begin{array}{lll}\text { Hirarki } & \text { Sistem } & \text { Pusat } \\
\text { Pelayanan } & & \end{array}$ & $66,67-88,88$ & 80,5 & 4 & Berpengaruh \\
\hline 2 & $\begin{array}{l}\text { Prinsip } \\
\text { Jarak/Aksesibilitas }\end{array}$ & $\begin{array}{l}\text { Rute Pelayanan } \\
\text { Jangkauan Pelayanan } \\
\text { Waktu Dan Biaya }\end{array}$ & $\begin{array}{c}66,67-88,88 \\
88,87-100 \\
88,87-100\end{array}$ & $\begin{array}{l}84,6 \\
92,4 \\
90,3\end{array}$ & $\begin{array}{l}4 \\
5 \\
5\end{array}$ & $\begin{array}{c}\text { Berpengaruh } \\
\text { Sangat Berpengaruh } \\
\text { Sangat Berpengaruh }\end{array}$ \\
\hline 3 & Prinsip Zonasi & $\begin{array}{l}\text { Tingkat Kepadatan } \\
\text { Penduduk }\end{array}$ & $66,67-88,88$ & 81,2 & 4 & Berpengaruh \\
\hline 4 & $\begin{array}{l}\text { Prinsip Tata Guna } \\
\text { Lahan }\end{array}$ & $\begin{array}{l}\text { Ketinggian Bangunan } \\
\text { Harga Lahan } \\
\text { Nilai Lahan } \\
\text { Intensitas Penggunaan } \\
\text { Lahan }\end{array}$ & $\begin{array}{l}66,67-88,88 \\
66,67-88,88 \\
66,67-88,88 \\
66,67-88,88\end{array}$ & $\begin{array}{l}86,2 \\
78 \\
72,1 \\
82,6\end{array}$ & $\begin{array}{l}4 \\
4 \\
4 \\
4\end{array}$ & $\begin{array}{l}\text { Berpengaruh } \\
\text { Berpengaruh } \\
\text { Berpengaruh } \\
\text { Berpengaruh }\end{array}$ \\
\hline 5 & $\begin{array}{l}\text { Prinsip Peruntukkan } \\
\text { Utama Fungsi } \\
\text { Kawasan Dan } \\
\text { Prinsip Penyediaan } \\
\text { Kawasan Bisnis }\end{array}$ & $\begin{array}{l}\text { Karakteristik Fisik Lahan } \\
\text { Ketersediaan Fasilitas } \\
\text { Perdagangan Dan Jasa }\end{array}$ & $\begin{array}{c}66,67-88,88 \\
88,87-100\end{array}$ & $\begin{array}{l}83,2 \\
91,4\end{array}$ & $\begin{array}{l}4 \\
5\end{array}$ & $\begin{array}{c}\text { Berpengaruh } \\
\text { Sangat Berpengaruh }\end{array}$ \\
\hline 6 & $\begin{array}{l}\text { Prinsip Integrasi } \\
\text { Dan Prinsip } \\
\text { Konektivitas }\end{array}$ & $\begin{array}{l}\text { Ketersediaan Jaringan Jalan } \\
\text { Ketersediaan Fasilitas Sosial } \\
\text { Dan Fasilitas Umum } \\
\text { Ketersediaan } \\
\text { Transportasi }\end{array}$ & $\begin{array}{l}88,87-100 \\
88,87-100\end{array}$ & $\begin{array}{l}95,2 \\
90,8\end{array}$ & $\begin{array}{l}5 \\
5\end{array}$ & $\begin{array}{l}\text { Sangat Berpengaruh } \\
\text { Sangat Berpengaruh }\end{array}$ \\
\hline & & & $88,87-100$ & 95,2 & 5 & Sangat Berpengaruh \\
\hline
\end{tabular}

Sumber: Hasil Analisis, 2020

Tabel 3 Metode Analisa Path/Jalur Dengan Uji Sobel

\begin{tabular}{|c|c|c|c|c|c|}
\hline Pengaruh Langsung & & \multicolumn{3}{|c|}{ Koefisien Jalur } & Standart Error \\
\hline Prinsip Jarak/Aksesibilitas Terhadap Bandara & & \multicolumn{3}{|c|}{$-0,152$} & 0,255 \\
\hline Prinsip Zonasi Terhadap Bandara & & \multicolumn{3}{|c|}{0,279} & 0,145 \\
\hline Prinsip Tata Guna Lahan Terhadap Bandara & & \multicolumn{3}{|c|}{0,144} & 0,240 \\
\hline Peruntukan Fungsi Kawasan Terhadap Bandara & & \multicolumn{3}{|c|}{0,091} & 0,135 \\
\hline Prinsip Intergrasi Dan Konektivitas & & \multicolumn{3}{|c|}{$-0,482$} & 0,204 \\
\hline Prinsip Struktur Ruang Terhadap Aerotropolis & & \multicolumn{3}{|c|}{$-0,255$} & 0,136 \\
\hline Bandara Terhadap Konsep Aerotropolis & & \multicolumn{3}{|c|}{0,421} & 0,117 \\
\hline Pengaruh Tidak Langsung & $\begin{array}{c}\text { Koefisien } \\
\text { Jalur }\end{array}$ & Sab & t hit & t/ttab & Keterangan \\
\hline PJA - Bandara - Aerotropolis & $-0,064$ & 0,01 & $-4,95$ & 2 & Tidak Singnifikan \\
\hline PZ - Bandara - Aerotropolis & 0,117 & 0,09 & 1,27 & 2 & Tidak Singnifikan \\
\hline PTGL - Bandara -Aerotropolis & 0,060 & 0,09 & 0,70 & 2 & Tidak Singnifikan \\
\hline PUFK - Bandara - Aerotropolis & 0,038 & 0,06 & 0,60 & 2 & Tidak Singnifikan \\
\hline PIK - Bandara - Aerotropolis & $-0,203$ & $-0,05$ & 4,35 & 2 & Singnifikan \\
\hline PSR - Bandara - Aerotropolis & $-0,107$ & 0,02 & $-6,31$ & 2 & Tidak Singnifikan \\
\hline
\end{tabular}

